\title{
Reduced glutamine concentration improves protein production in growth-arrested CHO-DG44 and HEK-293E cells
}

\author{
Yashas Rajendra $\cdot$ Divor Kiseljak $\cdot$ Lucia Baldi • \\ David L. Hacker • Florian M. Wurm
}

Received: 18 August 2011/Accepted: 22 November 2011/Published online: 30 November 2011

(C) Springer Science+Business Media B.V. 2011

\begin{abstract}
For most cultivated mammalian cells, glutamine is an essential medium component. However, glutamine consumption results in the production of ammonia, a cytotoxic byproduct. Here we investigated the effect of glutamine reduction on recombinant protein production and ammonia accumulation in transiently transfected $\mathrm{CHO}$ and HEK-293E cells maintained under conditions of growth arrest. Maximum transient recombinant protein yields were observed in HEK-293E cultures without glutamine and in $\mathrm{CHO}$ cultures with $2 \mathrm{mM}$ glutamine. The initial concentration of glutamine correlated with the level of ammonia accumulation in each culture. For both a stable CHO-derived cell line and a polyclonal population of recombinant $\mathrm{CHO}$ cells grown under conditions of mild hypothermia, the highest volumetric protein productivity was observed in cultures without glutamine. Here, the level of ammonia accumulation also corresponded to the initial glutamine
\end{abstract}

Yashas Rajendra and Divor Kiseljak are contributed equally to this work.

Y. Rajendra · D. Kiseljak · L. Baldi · D. L. Hacker

Laboratory for Cellular Biotechnology (LBTC),

École Polytechnique Fédéral de Lausanne

(EPFL), 1015 Lausanne, Switzerland

F. M. Wurm ( $\square)$

EPFL SV-IBI-LBTC, CH J2-506 (Building CH),

Station 6, 1015 Lausanne, Switzerland

e-mail: florian.wurm@epfl.ch concentration. Our data demonstrate that reduction of glutamine in the medium is an effective approach to improve protein production in both transiently and stably transfected mammalian cells when applying conditions that reduce or arrest the growth of these cells.

Keywords Ammonia - CHO-DG44 - Glutamine · HEK-293E · Stable gene expression .

Transient gene expression

\section{Introduction}

Glutamine is an important component in media for mammalian cell cultivation as it serves as a precursor for the synthesis of peptides, proteins, amino sugars, purines, and pyrimidines (Newsholme et al. 2003). It is also a major energy source along with glucose (Fitzpatrick et al. 1993; Schneider et al. 1996). The catabolism of glutamine, however, is associated with the production of ammonia, a cytotoxic byproduct which can reach up to $10 \mathrm{mM}$ in a typical batch culture (Ozturk et al. 1992). Even as low as $2 \mathrm{mM}$, ammonia has a negative impact on cell growth and recombinant protein production (Canning and Fields 1983; Hansen and Emborg 1994; Ito and McLimans 1981; Reuveny et al. 1986; Yang and Butler 2000b). Elevated ammonia levels can also result in lower terminal sialylation and higher glycan heterogeneity on glycosylated recombinant proteins (Andersen and 
Goochee 1995; Borys et al. 1994; Gawlitzek et al. 1998; Thorens and Vassalli 1986; Yang and Butler 2000b; Yang and Butler 2002). To overcome the toxic effects of ammonia on cells, glutamate, asparagine, and dipeptides such as L-alanyl-L-glutamine and glycyl-L-glutamine have been used as substitutes for glutamine (Altamirano et al. 2004; Capiaumont et al. 1995; Hassell et al. 1991). The removal of ammonia from cultures has also been attempted using electrokinetic techniques (Gawlitzek et al. 1995), gaspermeable hydrophobic membranes (Schneider et al. 1996), and immobilized adsorbents (Jeong and Wang 1992).

In this study we investigated the effect of glutamine reduction on recombinant protein production and ammonia accumulation in transiently transfected CHO-DG44 (CHO) and HEK-293E cells. For transient gene expression (TGE) in these two host cells, we routinely use mild hypothermia $\left(31^{\circ} \mathrm{C}\right)$ and valproic acid (VPA), respectively, to increase the volumetric productivity while concomitantly reducing cellular growth (Wulhfard et al. 2008; Backliwal et al. 2008). Under these conditions, the majority of transfected cells are growth-arrested in the $\mathrm{G} 1$ phase of the cell cycle. The rationale for lowering the amount of glutamine from cultures of growth-arrested cells was to reduce the level of ammonia accumulation with the expectation that this would improve recombinant protein production.

\section{Materials and methods}

Cell culture

Suspension-adapted CHO cells, a recombinant CHOderived cell line expressing an anti-Rhesus D IgG, and a polyclonal population of recombinant $\mathrm{CHO}$ cells expressing the same IgG were routinely cultivated in ProCHO5 medium (Lonza, Verviers, Belgium) supplemented with $13.6 \mathrm{mg}$ hypoxanthine/ $1,3.88 \mathrm{mg}$ thymidine/l, and $4 \mathrm{mM}$ glutamine (SAFC Biosciences, St. Louis, MO). For protein production, the polyclonal cell population and the clonal cell line were seeded at $5 \times 10^{6}$ cells $/ \mathrm{ml}$ in $100 \mathrm{ml}$ ProCHO5 medium in $250 \mathrm{ml}$ square-shaped bottles (Schott Glass, Mainz, Germany) and maintained at $31^{\circ} \mathrm{C}$ with $5 \% \mathrm{CO}_{2}$ and $85 \%$ humidity with agitation at $120 \mathrm{rpm}$ (Muller et al. 2005). Suspension-adapted
HEK-293E cells were cultivated in Ex-Cell293 medium (SAFC Biosciences) with $4 \mathrm{mM}$ glutamine in orbitally-shaken square-shaped bottles at $37^{\circ} \mathrm{C}$. Cell viability was assessed by the Trypan Blue exclusion method.

\section{Transfection of CHO cells}

One day prior to transfection, cells were seeded at $2 \times 10^{6}$ cells $/ \mathrm{ml}$ in ProCHO5. The next day, the cells were centrifuged and resuspended in ProCHO5 at $5 \times 10^{6}$ cells $/ \mathrm{ml}$. Transfections were performed in $250 \mathrm{ml}$ square-shaped glass bottles using $25 \mathrm{kDa}$ polyethyleneimine (PEI; dissolved in water at $1 \mathrm{mg} / \mathrm{ml}$ and $\mathrm{pH}$ 7) for DNA delivery. Each transfection was performed in $100 \mathrm{ml}$ by sequential addition of pXLG ${ }^{\mathrm{CHO}}-\mathrm{A} 3$ DNA (0.6 $\mu \mathrm{g} /$ million cells), a plasmid expressing the light and heavy chain genes of a human anti-Rhesus D IgG1 and PEI ( $3.0 \mu \mathrm{g} /$ million cells) (Rajendra et al. 2011). The transfected cultures were maintained at $31^{\circ} \mathrm{C}$ with $5 \% \mathrm{CO}_{2}$ and $85 \%$ humidity and with agitation at $120 \mathrm{rpm}$.

\section{Transfection of HEK-293E cells}

One day prior to transfection, cells were seeded at $10^{6}$ cells $/ \mathrm{ml}$ in Ex-Cell293. The next day, cells were centrifuged and resuspended in $5 \mathrm{ml}$ RPMI 1640 medium at $20 \times 10^{6}$ cells/ml. pXLG ${ }^{\mathrm{CHO}}-\mathrm{A} 3(1.5 \mu \mathrm{g} /$ million cells) and PEI $(3 \mu \mathrm{g} /$ million cells $)$ were sequentially added to the culture, and at $3 \mathrm{~h}$ posttransfection, the cells were diluted with $95 \mathrm{ml}$ Ex-Cell293 medium in $250 \mathrm{ml}$ square-shaped glass bottles and VPA (500 $\mathrm{mM}$ in water) (Sigma-Aldrich) was added to the culture to $3.75 \mathrm{mM}$. The transfected cultures were maintained in an incubator shaker at $37^{\circ} \mathrm{C}$ with $5 \% \quad \mathrm{CO}_{2}$ and $85 \%$ humidity and with agitation at $120 \mathrm{rpm}$.

\section{Analyses}

Glucose, glutamine, ammonium, and lactate were determined using a BioProfile 200 Bioanalyzer (Nova Biomedical Corp., Waltham, MA). The IgG concentration in the culture medium was determined by sandwich ELISA as previously described (Meissner et al. 2001). 


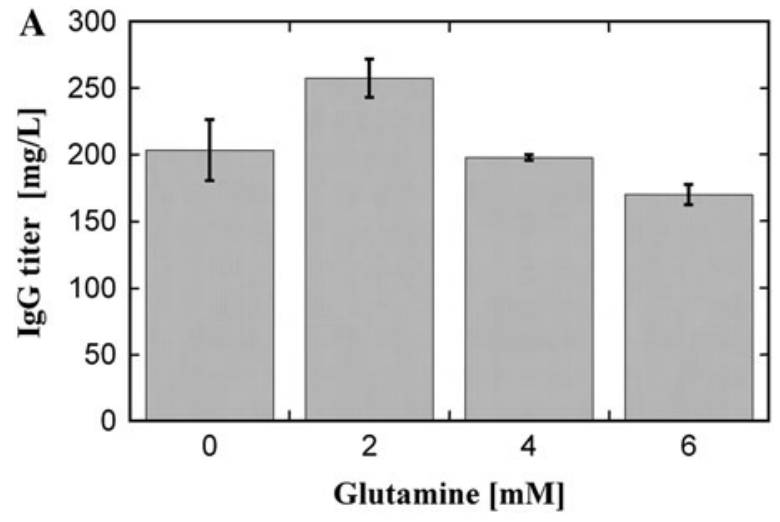

Fig. 1 Effect of glutamine on recombinant $\mathrm{IgG}$ production in transiently transfected cells. CHO (a) and HEK-293E cells (b) were transfected with $\mathrm{pXLG}{ }^{\mathrm{CHO}}-\mathrm{A} 3$ and maintained at either $31^{\circ} \mathrm{C}(\mathrm{CHO})$ or $37^{\circ} \mathrm{C}$ in the presence of $3.75 \mathrm{mM} \mathrm{VPA}$
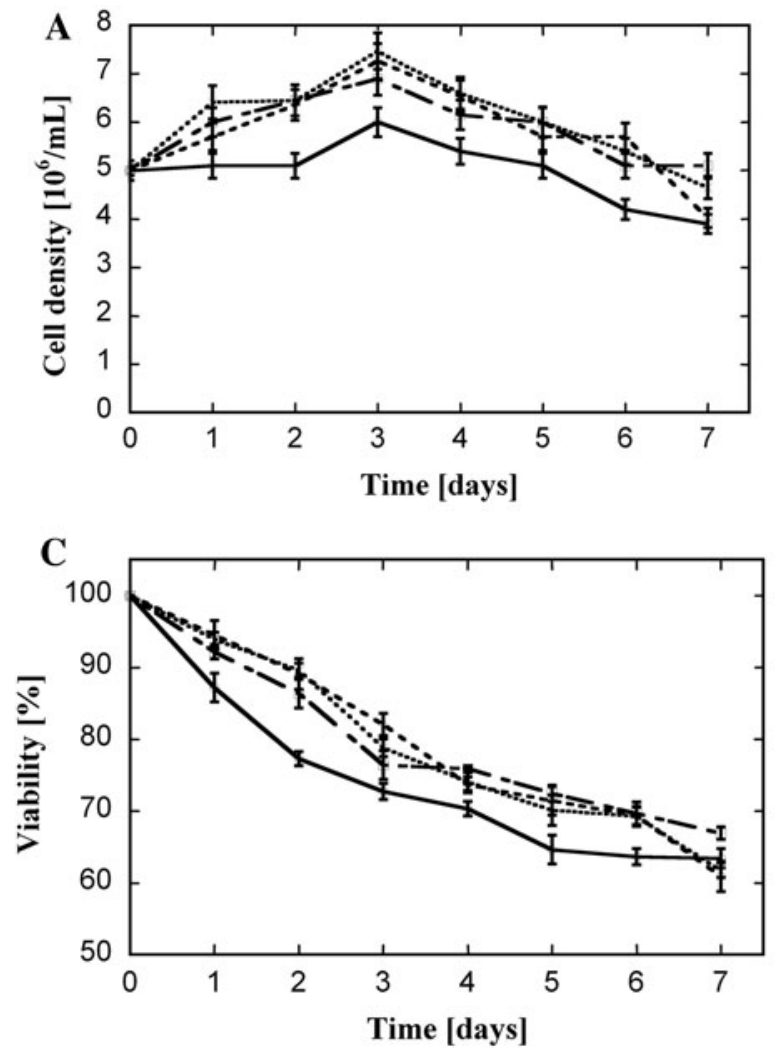

Fig. 2 The effect of glutamine on cultures of transiently transfected cells. CHO (a, c) and HEK-293E cells (b, d) were transfected as described in Fig. 1. The cell density (a, b) and viability $(\mathbf{c}, \mathbf{d})$ were measured at the times indicated by the

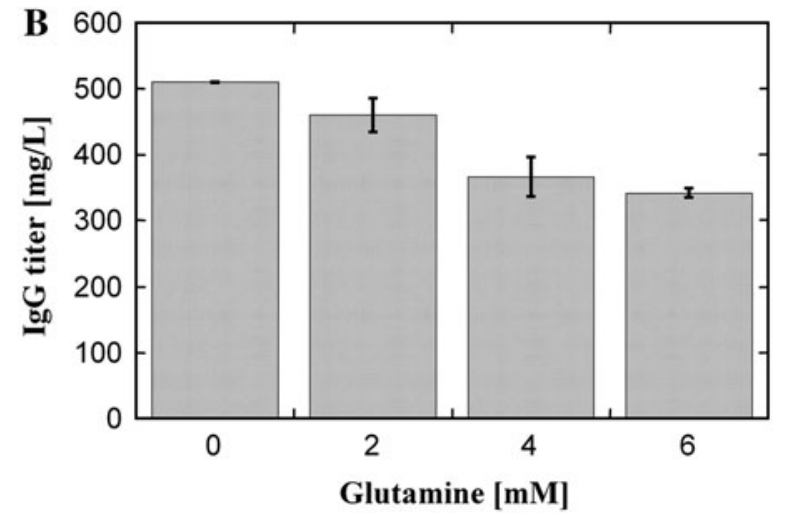

(HEK-293E). The initial concentration of glutamine in the medium is indicated. The $\mathrm{IgG}$ titer was determined on day 7 post-transfection by ELISA
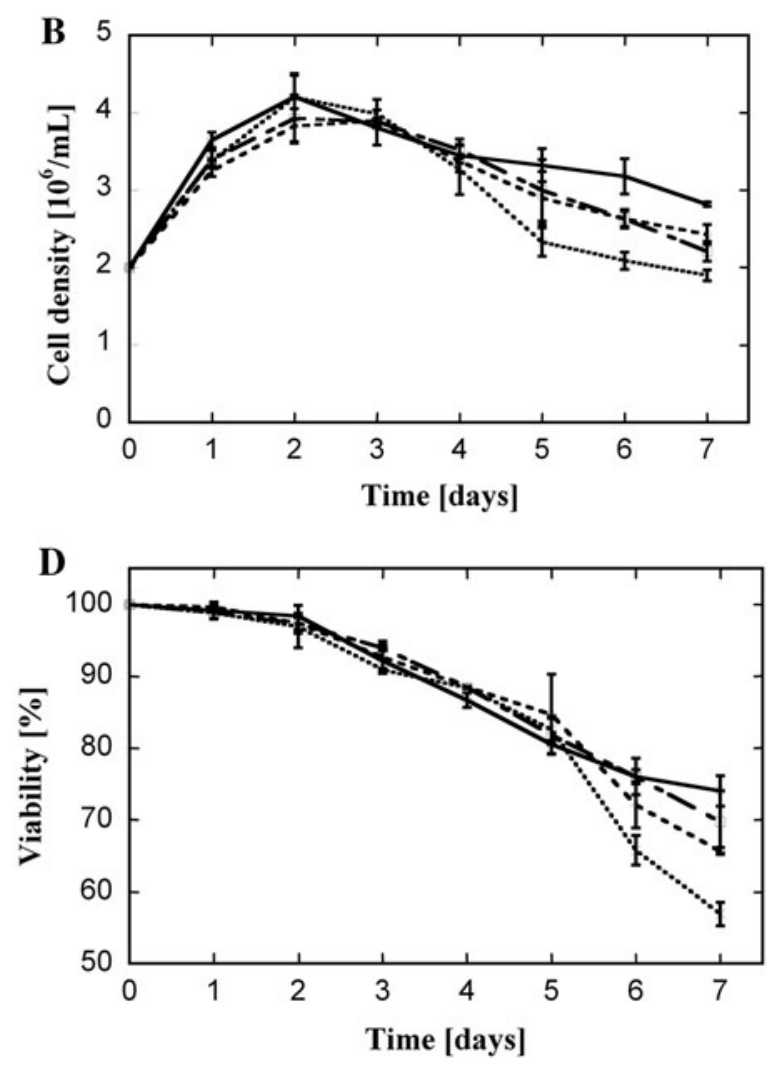

Trypan blue exclusion method. The initial glutamine concentration in the medium was $0 \mathrm{mM}$ (thick line), $2 \mathrm{mM}$ (dashed thick line), $4 \mathrm{mM}$ (dashed line), or $6 \mathrm{mM}$ (dotted line) 

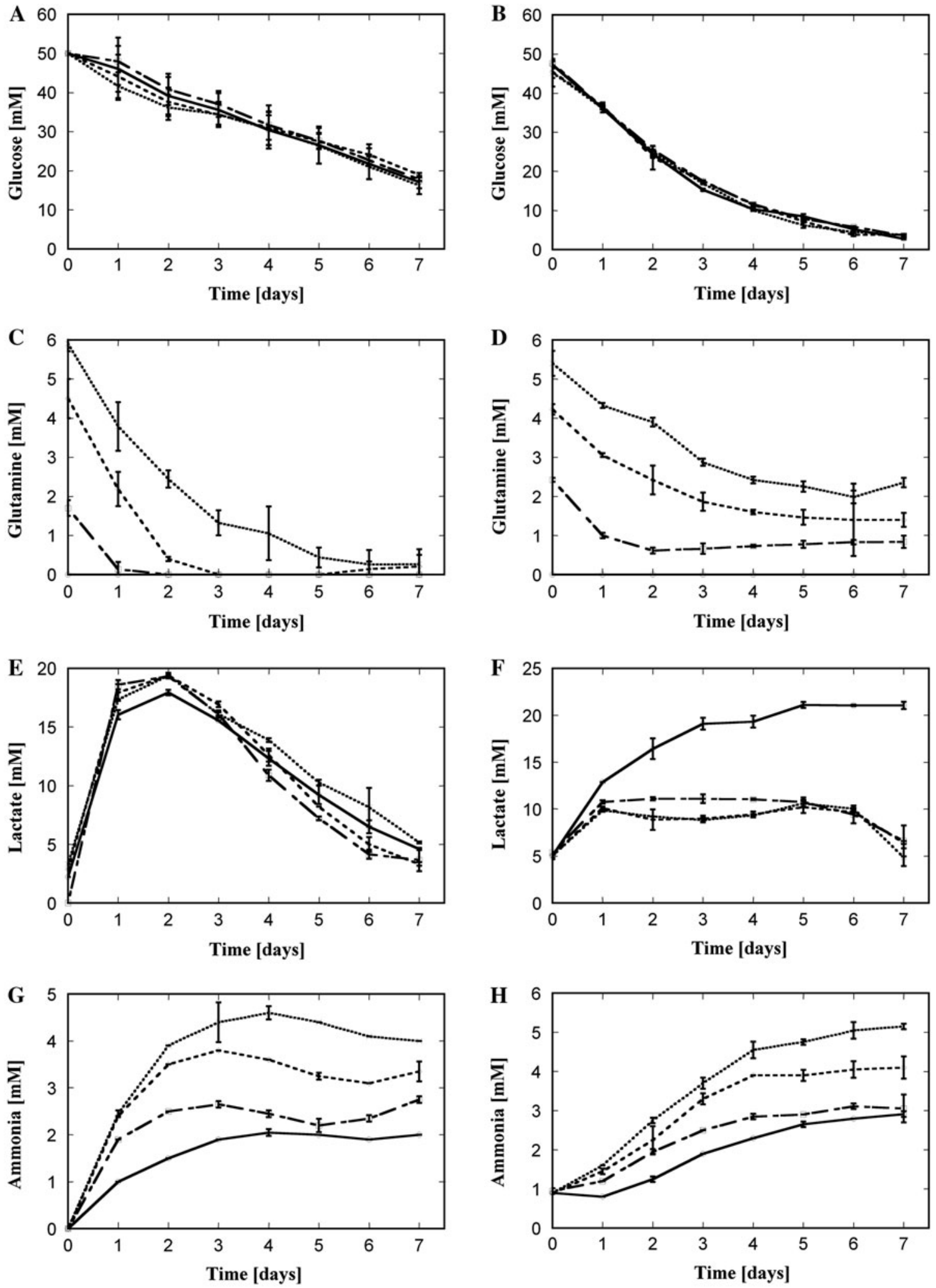
4Fig. 3 Effect of glutamine on cultures of transiently transfected cells. CHO (a, c, e, g) and HEK-293E cells (b, d, f, h) were transfected as described in Fig. 1. At the times indicated the levels of glucose $(\mathbf{a}, \mathbf{b})$, glutamine $(\mathbf{c}, \mathbf{d})$, lactate $(\mathbf{e}, \mathbf{f})$, and ammonia $(\mathbf{g}, \mathbf{h})$ were measured. The initial glutamine concentration in the medium was $0 \mathrm{mM}$ (thick line), $2 \mathrm{mM}$ (dashed thick line), $4 \mathrm{mM}$ (dashed line), or $6 \mathrm{mM}$ (dotted line)

\section{Results}

Lowering of glutamine concentration improves transient protein production by $\mathrm{CHO}$ and HEK-293E cells

Suspension cultures of both CHO and HEK-293E cells were transiently transfected in medium with 0-6 mM glutamine. While the observed yield differences over this range of glutamine concentrations were moderate, the highest $\mathrm{IgG}$ concentrations were observed in the presence of $2 \mathrm{mM}$ glutamine for $\mathrm{CHO}$ cells (Fig. 1a) and in the absence of glutamine for HEK-293E cells (Fig. 1b). Maximum IgG production reached $250 \mathrm{mg} / \mathrm{l}$ for CHO (Fig. 1a) and $500 \mathrm{mg} / \mathrm{l}$ for HEK-293E cells (Fig. 1b). For CHO cells, the absence of glutamine negatively affected cell density (Fig. 2a), but this was not the case for HEK-293E cells (Fig. 2b). The absence of glutamine also had a negative effect on the viability of CHO cells (Fig. 2c) but not on HEK-293E cells (Fig. 2d). For transfections performed with $\mathrm{CHO}$ and HEK-293E cells which were not growth arrested, no positive effect of reduced glutamine on transient IgG production was observed (data not shown).

To better understand the improvements in transient protein production described above, glucose and glutamine consumption along with ammonia and lactate accumulation were measured over the duration of the cultures. Glucose consumption was not affected by the initial amount of glutamine in the culture (Fig. 3a, b). In cultures of transfected $\mathrm{CHO}$ cells with initial glutamine concentrations of 2 and $4 \mathrm{mM}$, the glutamine was depleted by day 2 and 3 post-transfection, respectively (Fig. 3c). In contrast, in cultures of transfected HEK-293E cells, the glutamine was not depleted (Fig. 3d). In cultures of CHO cells, the lactate concentration reached $15-20 \mathrm{mM}$ and then declined, due to its consumption (Fig. 3e). In cultures of HEK293E cells, the lactate concentration remained between 5 and $10 \mathrm{mM}$ in the presence of glutamine but increased to $20 \mathrm{mM}$ in the absence of glutamine
(Fig. 3f). The kinetics of ammonia accumulation correlated with the initial glutamine concentration for both cell lines (i.e. the higher the initial glutamine concentration, the greater the accumulation of ammonia in the culture) (Fig. 3g, h). However, ammonia was produced even when glutamine was not added to the culture media (Fig. 3g, h). We tested the effect of the addition of $2-6 \mathrm{mM} \mathrm{NH} \mathrm{Nl}_{4} \mathrm{Cl}$ to transiently transfected CHO and HEK-293E cells in cultures lacking glutamine. At all concentrations tested, $\mathrm{NH}_{4} \mathrm{Cl}$ had a negative effect on transient IgG production for both cell hosts (data not shown). To determine if a reduced glutamine concentration enhanced the transient production of other proteins, $\mathrm{CHO}$ cells were transfected with a plasmid coding for either tumor necrosis factor receptor-Fc (TNFR-Fc) or leukemia inhibitory factor$\mathrm{Fc}(\mathrm{LIF}-\mathrm{Fc})$ fusion protein and cultivated in medium with various amounts of glutamine $(0-6 \mathrm{mM})$. We observed up to $30 \%$ improvement in the titers of both recombinant fusion proteins at $2 \mathrm{mM}$ glutamine as compared to $6 \mathrm{mM}$ (data not shown). The maximum titers at day 7 post-transfection were $240 \mathrm{mg} / \mathrm{l}$ for TNFR-Fc and $260 \mathrm{mg} / \mathrm{l}$ for LIF-Fc.

The absence of glutamine improves protein production by monoclonal or polyclonal CHO cells

The effect of glutamine on recombinant protein production from a $\mathrm{CHO}$-derived cell line and a recombinant polyclonal population (pool) of $\mathrm{CHO}$ cells under mild hypothermia was also determined. In both cases, the highest protein production was observed in cultures without glutamine (Fig. 4a). For the CHO-derived cell line, cell growth, glucose and glutamine consumption, and ammonia and lactate accumulation were measured over the duration of each culture. No significant differences were observed in cell density at the various glutamine concentrations tested (Fig. 4b). The viability of the cultures remained above $95 \%$ over 7 days (data not shown). In cultures with an initial glutamine concentration of 2 or $4 \mathrm{mM}$, the glutamine was depleted by day 2 post-inoculation (Fig. 4c). For all four cultures, glutamine was produced after day 2 (Fig. 4c). For the first 2 days of culture, ammonia accumulated. Afterwards, it was consumed (Fig. 4d). No significant differences were observed in glucose consumption and lactate production for the four cultures (data not shown). In contrast 

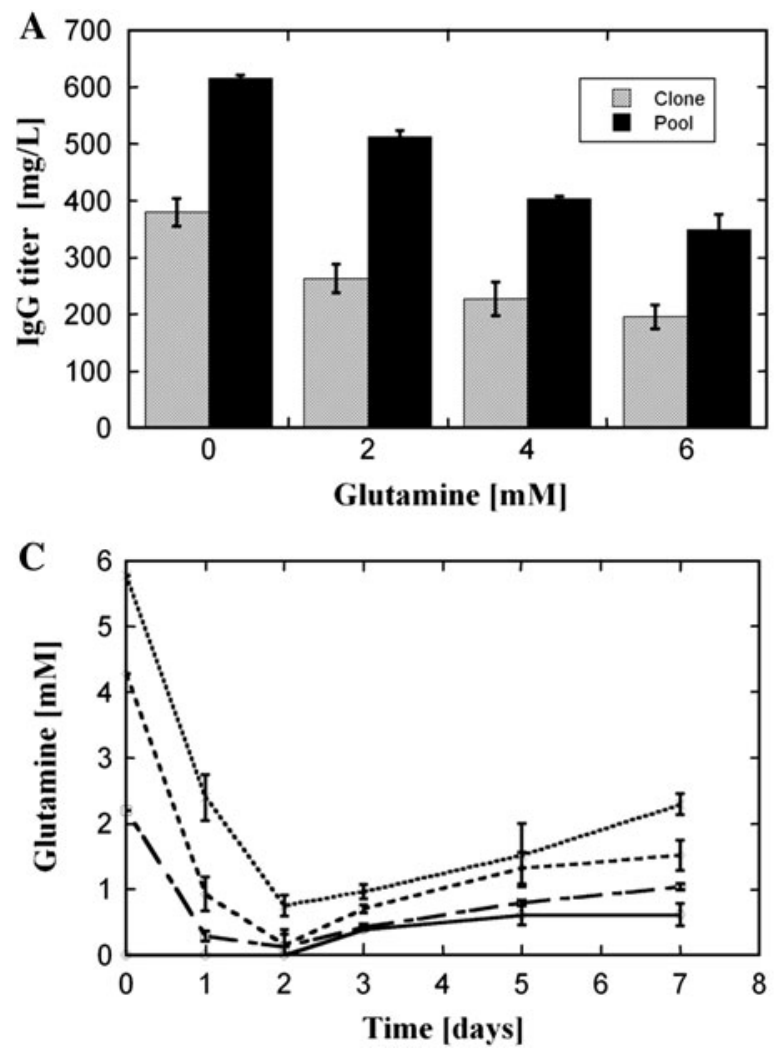

Fig. 4 Effect of glutamine on a CHO-derived cell line and polyclonal population. A recombinant $\mathrm{CHO}$-derived cell line (clone) and a polyclonal population of recombinant $\mathrm{CHO}$ cells (pool) were seeded at $5 \times 10^{6}$ cells $/ \mathrm{ml}$ in ProCHO5 with different amounts of glutamine as indicated and maintained in an incubator shaker at $31^{\circ} \mathrm{C}$ with agitation at $120 \mathrm{rpm}$. The $\mathrm{IgG}$

to the results generated under hypothermic conditions, we observed a negative effect on protein production when the cell line and the polyclonal population were cultivated in the absence of glutamine at $37^{\circ} \mathrm{C}$ (data not shown).

\section{Discussion}

The objective of this study was to determine the effect of glutamine on transient recombinant protein production and ammonia accumulation in growtharrested CHO and HEK-293E cells. Under conditions of mild hypothermia, $\mathrm{CHO}$ cells are arrested in the G1 phase of the cell cycle (Wulhfard et al. 2008). In the presence of VPA, HEK-293E cells have a reduced growth rate (Unpublished results). We speculated that under such conditions, glutamine could be reduced in
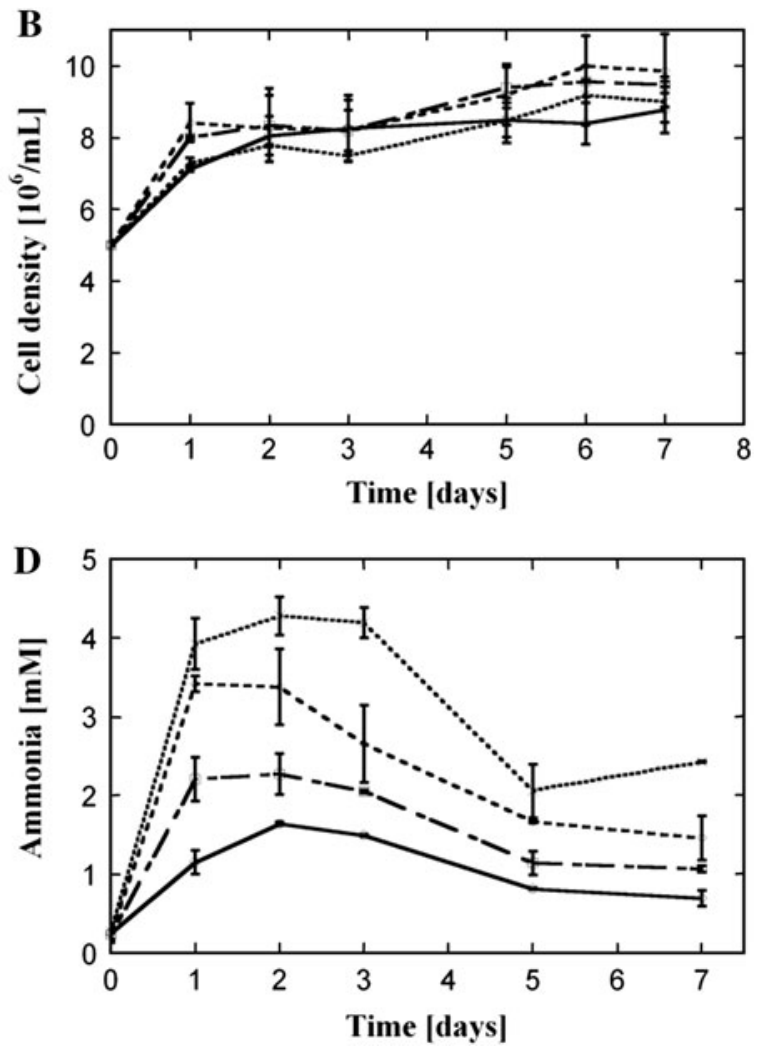

titer of each culture was determined on day 7 post-inoculation by ELISA (a). For the cultures of the CHO clone, the cell density (b), glutamine concentration (c), and ammonia concentration (d) were measured at the times indicated. The initial glutamine concentration in the medium was $0 \mathrm{mM}$ (thick line), $2 \mathrm{mM}$ (dashed thick line), $4 \mathrm{mM}$ (dashed line), or $6 \mathrm{mM}$ (dotted line)

concentration or eliminated from the medium without negative consequences on transient protein production. By reducing glutamine consumption, it was expected that the cells would produce less ammonia (Schneider et al. 1996). At low concentrations ammonia has a negative effect on cell growth and metabolism and on recombinant protein production and quality (Canning and Fields 1983; Hansen and Emborg 1994; Ito and McLimans 1981; Reuveny et al. 1986; Yang and Butler 2000b). While the observed benefits in transient protein production described here were moderate, the highest yields were found at $2 \mathrm{mM}$ glutamine for cultures of transfected $\mathrm{CHO}$ cells and without glutamine for cultures of transfected HEK-293E cells. The results were confirmed for the transient production in transfected $\mathrm{CHO}$ cells of two Fc-fusion proteins. The positive effect of glutamine reduction on recombinant protein 
production was also found for a stable $\mathrm{CHO}$-derived cell line and a polyclonal population of recombinant $\mathrm{CHO}$ cells under conditions of growth arrest.

In cultures of transfected and growth-arrested $\mathrm{CHO}$ and HEK-293E cells, we observed a direct correlation between the initial amount of glutamine and the level of ammonia accumulation in the medium. Under conditions for optimum transient protein production (2 mM glutamine for $\mathrm{CHO}$ cells and $0 \mathrm{mM}$ glutamine for HEK-293E cells), ammonia accumulation reached about $2.5 \mathrm{mM}$. A similar level of ammonia accumulation was seen for the cultivation of a $\mathrm{CHO}$-derived cell line under hypothermic conditions in the presence of $2 \mathrm{mM}$ glutamine. At the highest glutamine concentration tested $(6 \mathrm{mM})$, we observed the accumulation of 4-5 mM ammonia in cultures of transfected CHO and HEK-293E cells. Under these conditions, a reduced recombinant protein yield was observed relative to that at the optimal glutamine concentration. However, there was not a noticeable effect of 4-5 mM ammonia on cell growth and viability. Interestingly, we found that the addition of ammonium chloride at concentrations as low as $2 \mathrm{mM}$ to cultures of transfected cells had a negative effect on transient protein production. Together, the results suggest that the improvement in transient recombinant protein yields when glutamine was reduced (transiently or stably transfected CHO cells) or eliminated (HEK-293E cells) could be due, at least in part, to the reduction in the level of ammonia accumulation in these cultures.

A negative effect of glutamine on the specific consumption rates of amino acids by cultivated mammalian cells has been observed previously (Vriezen et al. 1997). Moreover, ammonia accumulation has also been shown to have a negative impact on amino acid consumption by cultivated mammalian cells (Yang and Butler 2000a). Thus, it remains possible that altered amino acid metabolism at lower initial glutamine concentrations plays a role in the improvement in recombinant protein yields observed here.

For transfected HEK-293E cells, the absence of glutamine in the medium resulted in an increase in lactate production as compared to cultures containing glutamine at concentrations of $2 \mathrm{mM}$ or more. We speculate that the absence of glutamine may result in lower levels of glutamate production which in turn could lead to the accumulation of pyruvate and lactate in these cells. In CHO cells, on the other hand, lactate was consumed after day 2 post-transfection despite the availability of glucose in agreement with previously published data (Altamirano et al. 2006; Tsao et al. 2005). For the transfected CHO and HEK-293E cultures described here, the lactate concentrations observed were relatively low compared to the concentrations shown to have a negative effect impact on cell viability and protein productivity (Reuveny et al. 1986).

In conclusion, our results demonstrated that the reduction of glutamine during the production phase of a bioprocess is a simple strategy for increasing recombinant protein yield. However, more studies need to be done to fully understand the physiological effects of glutamine reduction on cultures of transfected and growth-arrested CHO and HEK-293E cells.

\section{References}

Altamirano C, Paredes C, Illanes A, Cairo JJ, Godia F (2004) Strategies for fed-batch cultivation of t-PA producing $\mathrm{CHO}$ cells: substitution of glucose and glutamine and rational design of culture medium. J Biotechnol 110(2):171-179

Altamirano C, Illanes A, Becerra S, Cairo JJ, Godia F (2006) Considerations on the lactate consumption by $\mathrm{CHO}$ cells in the presence of galactose. J Biotechnol 125(4):547-556

Andersen DC, Goochee CF (1995) The effect of ammonia on the O-linked glycosylation of granulocyte colony-stimulating factor produced by Chinese hamster ovary cells. Biotechnol Bioeng 47(1):96-105

Backliwal G, Hildinger M, Chenuet S, Wulhfard S, De Jesus M, Wurm FM (2008) Rational vector design and multi-pathway modulation of HEK-293E cells yield recombinant antibody titers exceeding $1 \mathrm{~g} / \mathrm{l}$ by transient transfection under serum-free conditions. Nucleic Acids Res 36(15): e96

Borys MC, Linzer DI, Papoutsakis ET (1994) Ammonia affects the glycosylation patterns of recombinant mouse placental lactogen-I by Chinese hamster ovary cells in a $\mathrm{pH}$-dependent manner. Biotechnol Bioeng 43(6):505-514

Canning WM, Fields BN (1983) Ammonium chloride prevents lytic growth of reovirus and helps to establish persistent infection in mouse L cells. Science 219(4587):987-988

Capiaumont J, Legrand C, Carbonell D, Dousset B, Belleville F, Nabet P (1995) Methods for reducing the ammonia in hybridoma cell cultures. J Biotechnol 39(1):49-58

Fitzpatrick L, Jenkins HA, Butler M (1993) Glucose and glutamine metabolism of a murine B-lymphocyte hybridoma grown in batch culture. Appl Biochem Biotechnol 43(2): 93-116

Galbraith DJ, Tait AS, Racher AJ, Birch JR, James DC (2006) Control of culture environment for improved polyethylenimine-mediated transient production of recombinant monoclonal antibodies by $\mathrm{CHO}$ cells. Biotechnol Prog 22(3):753-762

Gawlitzek M, Conradt HS, Wagner R (1995) Effect of different cell culture conditions on the polypeptide integrity and 
$N$-glycosylation of a recombinant model glycoprotein. Biotechnol Bioeng 46(6):536-544

Gawlitzek M, Valley U, Wagner R (1998) Ammonium ion and glucosamine dependent increases of oligosaccharide complexity in recombinant glycoproteins secreted from cultivated BHK-21 cells. Biotechnol Bioeng 57(5): 518-528

Greenblatt DY, Vaccaro AM, Jaskula-Sztul R, Ning L, Haymart M, Kunnimalaiyaan M, Chen H (2007) Valproic acid activates notch-1 signaling and regulates the neuroendocrine phenotype in carcinoid cancer cells. Oncologist 12(8):942-951

Hansen HA, Emborg C (1994) Influence of ammonium on growth, metabolism, and productivity of a continuous suspension Chinese hamster ovary cell culture. Biotechnol Prog 10(1):121-124

Hassell T, Gleave S, Butler M (1991) Growth inhibition in animal cell culture. The effect of lactate and ammonia. Appl Biochem Biotechnol 30(1):29-41

Ito M, McLimans WF (1981) Ammonia inhibition of interferon synthesis. Cell Biol Int Rep 5(7):661-666

Jeong YH, Wang SS (1992) In situ removal of ammonium ions from hybridoma cell culture media: selection of adsorbent. Biotechnol Technol 6(4):341-346

Meissner P, Pick H, Kulangara A, Chatellard P, Friedrich K, Wurm FM (2001) Transient gene expression: recombinant protein production with suspension-adapted HEK293EBNA cells. Biotechnol Bioeng 75(2):197-203

Muller N, Girard P, Hacker DL, Jordan M, Wurm FM (2005) Orbital shaker technology for the cultivation of mammalian cells in suspension. Biotechnol Bioeng 89(4): 400-406

Newsholme P, Procopio J, Lima MM, Pithon-Curi TC, Curi R (2003) Glutamine and glutamate - their central role in cell metabolism and function. Cell Biochem Funct 21(1):1-9

Ozturk SS, Riley MR, Palsson BO (1992) Effects of ammonia and lactate on hybridoma growth, metabolism, and antibody production. Biotechnol Bioeng 39(4):418-431

Rajendra Y, Kiseljak D, Baldi L, Hacker DL, Wurm FM (2011) A simple high-yielding process for transient gene expression in CHO cells. J Biotechnol 153(1-2):22-26

Reuveny S, Velez D, Macmillan JD, Miller L (1986) Factors affecting cell growth and monoclonal antibody production in stirred reactors. J Immunol Methods 86(1):53-59
Sami S, Hoti N, Xu HM, Shen Z, Huang X (2008) Valproic acid inhibits the growth of cervical cancer both in vitro and in vivo. J Biochem 144(3):357-362

Schmid G, Keller T (1992) Monitoring hybridoma metabolism in continuous suspension culture at the intracellular level. I. Steady-state responses to different glutamine feed concentrations. Cytotechnology 9(1-3):217-229

Schneider M, Marison IW, von Stockar U (1996) The importance of ammonia in mammalian cell culture. J Biotechnol 46(3):161-185

Thorens B, Vassalli P (1986) Chloroquine and ammonium chloride prevent terminal glycosylation of immunoglobulins in plasma cells without affecting secretion. Nature 321(6070):618-620

Tsao YS, Cardoso AG, Condon RG, Voloch M, Lio P, Lagos JC, Kearns BG, Liu Z (2005) Monitoring Chinese hamster ovary cell culture by the analysis of glucose and lactate metabolism. J Biotechnol 118(3):316-327

Vriezen N, Romein B, Luyben KC, van Dijken JP (1997) Effects of glutamine supply on growth and metabolism of mammalian cells in chemostat culture. Biotechnol Bioeng 54(3):272-286

Wulhfard S, Tissot S, Bouchet S, Cevey J, De Jesus M, Hacker DL, Wurm FM (2008) Mild hypothermia improves transient gene expression yields several fold in Chinese hamster ovary cells. Biotechnol Prog 24(2):458-465

Wulhfard S, Baldi L, Hacker DL, Wurm F (2010) Valproic acid enhances recombinant mRNA and protein levels in transiently transfected Chinese hamster ovary cells. J Biotechnol 148(2-3):128-132

Yang M, Butler M (2000a) Effects of ammonia on CHO cell growth, erythropoietin production, and glycosylation. Biotechnol Bioeng 68(4):370-380

Yang M, Butler M (2000b) Enhanced erythropoietin heterogeneity in a $\mathrm{CHO}$ culture is caused by proteolytic degradation and can be eliminated by a high glutamine level. Cytotechnology 34(1-2):83-99

Yang M, Butler M (2002) Effects of ammonia and glucosamine on the heterogeneity of erythropoietin glycoforms. Biotechnol Prog 18(1):129-138 